\title{
The Factorial Structure and Psychometric Properties of the Short use of Creative Cognition Scale in Studying
}

\author{
Meysam Shah Hossaini ${ }^{1}$, Hassan Nowroozi ${ }^{2}$, Afzal Akbari Balot Bangan ${ }^{3}$, Amir Hossein \\ Afshari $^{4}$ \\ 1-Student, Master of Psychology, Semnan University, Semnan, Iran \\ 2-Master of Clinical Psychology, Semnan University, Semnan, Iran. \\ 3-Student, PhD in Educational Psychology, Semnan University, Semnan, Iran \\ 4-Student, Master of Psychology, Semnan University, Semnan, Iran.
}

\begin{abstract}
Introduction: Creativity is one of the most important features of human which is essential for achieving the success, so assessment of creativity is vital.

Aim: The aim of this study was to examine the Psychometric properties of the short use of creative cognition scale in studying.

Method: For this purpose, 300 students (150 boys and 150 girls) were selected by cluster sampling method \&responded to short use of creative cognition for studying, meta-cognition and positive met cognition and meta-emotion Questionnaires. Exploratory and conformity factor analysis, Pearson relation and Cronbach's alpha were used to examine the Psychometric properties of scale. SPSS ${ }_{\mathrm{V} 22}$ and LISRELV8.80 software's were used for Data analyze.
\end{abstract}

Results: Exploratory factor analysis shows that the scale includes of one factor that predicts $51.73 \%$ of scale general variance, additionally conformity factor analysis showed that the scale has appropriate index (RMSEA=0.093). Examination of Convergent Validity using meta-cognition and positive met cognition and meta-emotion Questionnaires revealed that they had positive and significant relation with the scale. The result of internal consistency examination showed that scale Cronbach's alpha was 0.71 means it has suitable internal consistency.

Conclusion: according to finding it can be concluded that Persian form of Short use of creative cognition for studying scale has an acceptable psychometric properties among Iranian student community and it can be used as a valid instrument in psychological research.

Keywords: Creative Cognition for Studying Scale, Factorial Structure 


\title{
ساختار عاملى و خصوصيات روانسنجى مقياس شناخت خلاق براى مطالعه
}

\author{
ميثم شاهحينى '، حسن نوروزى'، افضل اكبرى بلوط بنغان '، اميرحسين افشارىع \\ ا.دانشجوى كارشناسى ارشد روانشناسى عمومى دانشكاه سمنان، سمنان، ايران

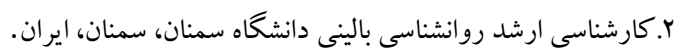

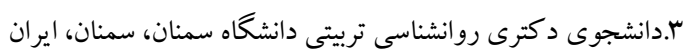

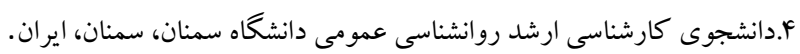

جكيده

مقدمه: خلاق بودن يكى از مهم ترين توانايىهاى انسان است كه براى دست يابى به موفقيت اهميت دارد. ازاينرو سنجش خلاقيت حائز اهميت هست.

هدف: هدف از يزوهش حاضر بررسى ساختار عاملى و خصوصيات روانسنجى مقياس شناخت خلاق براى مطالعه بود. روش: بِ از ترجمه-بازترجمه سؤالات مقياس شناخت خلاق، تعداد ... نفر از دانشجويان دانشگاه سمنان بهعنوان نمونه به روش نمونه گيرى در دسترس انتخاب شدند و به مقياس شناخت خلاق براى مطالعه و ير سشنامههاى فراشناخت و فراشناخت مثبت

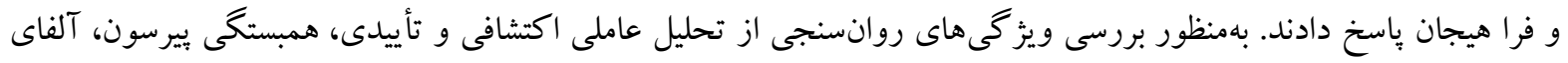

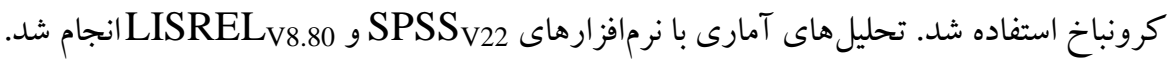
يافتها: نتايج تحليل عاملى اكتشافى نشان داد كه مقياس شناخت خلاق براى مطالعه از يكك عامل تشكيلشده است كه 1/V9

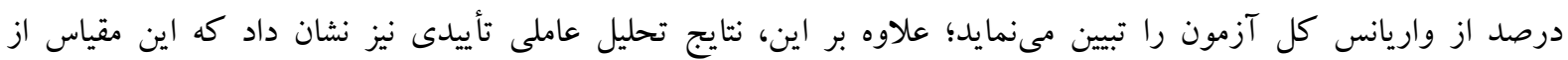

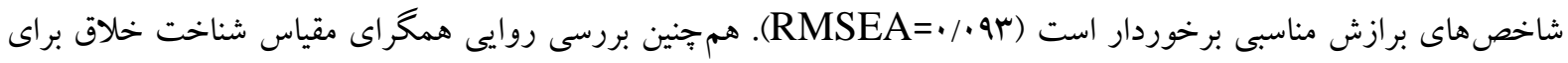

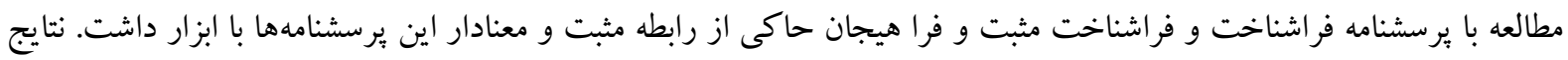

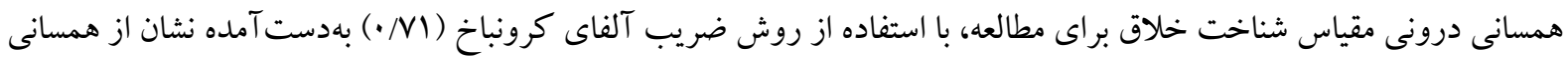
درونى رضايتبخش اين ابزار داشت. نتيجه كيرى: يافتهاى برزوهش بيانگر اين است كه نسخه فارسى مقياس شناخت خلاق براى مطالعه در جامعه دانشجويان از

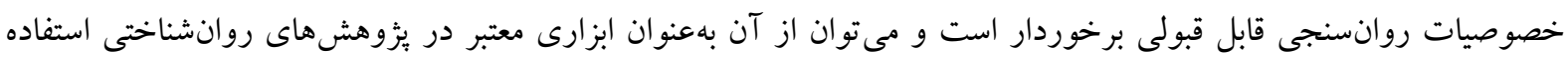


حر كات نوين در آينده را خلاقيت و ميزان بهره كيرى از تفكر خلاق تشكيل مىدهد كه سبكهاى تفكر خلاق نقش عمدهاى در ميزان خلاقيت هر فرد دارد

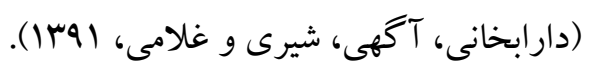
بر اين اساس، يكى از جالشهاى جدى إنى و قابل

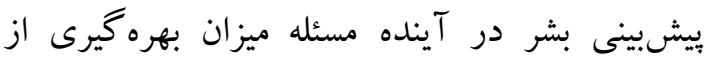

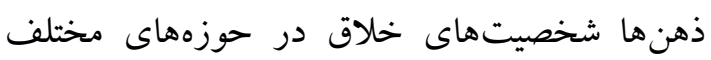
علمى، بزّوهشى، فناورانه و بهاشتى است (يير خائفى،

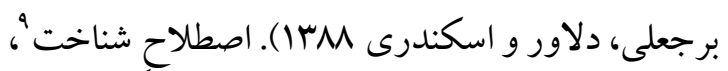
به فرآيندهاى درونى ذهنى يا راههايى كه در آنها

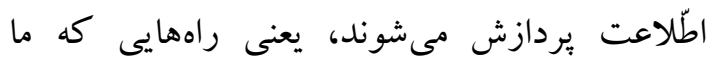
بلوسيلة آنها اطلاعات را موردتوجه قرار مىدهيم، آنها را تشخيص مىدهيم و به رمز درمى آوريم و در حافظه ذخيره مىسازيم و هر وقت كه نياز داشته باشيم آنها را از حافظه فرامىخوانيم و مورداستفاده قرار

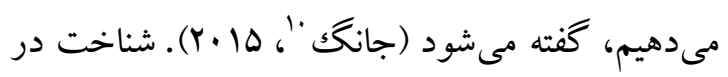
زبان روزمره به معناى دانستن است ولى در زبان

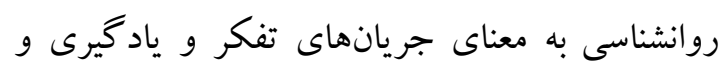

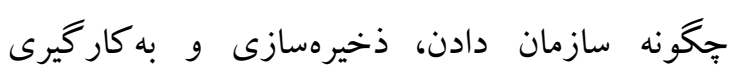
اطلاعات است (كاگك و برلينر "، 1994). راهبردهاى دهاى شناختى r' شامل راههايى هستند كه از طريق آن افراد

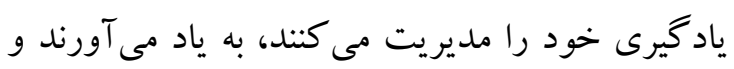
تفكر مى كنند و راههايى را در اختيار فرد قرار مىدهد رديد تا مسائل را با روشىهاى خلاقانه رفع نمايد (برون،

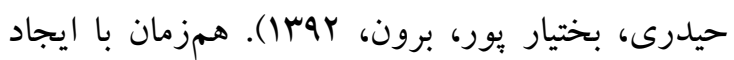

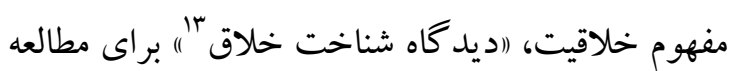

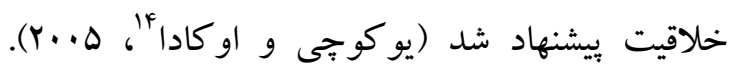

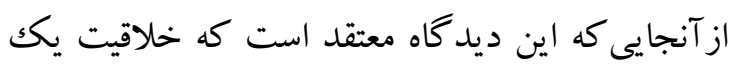

\footnotetext{
9. Cognition

${ }^{10}$.jang

11. Gage \& Berliner

12. Cognition Strategies

13. Creative Cognition Prospective

14. Yokochi \& Okada
}

مقلهم

توانايى خلاق بودن (همراه با توانايى تحليلى و عملى) يكى از سه توانايى عمده انسان است كه براى

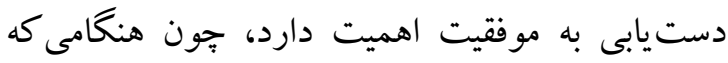

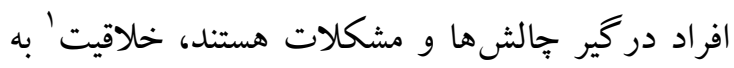

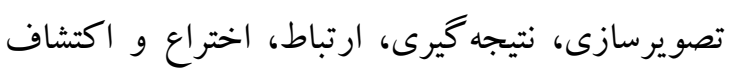
در افراد كمكك خواهد كرد (زبانوس و لبرت بـ 19 19). باينوجود در تبيين خلاقيت، نظريههاى مختلفى وجود دارد كه در جاى خود توضيحى روشنكرانه براى عوامل مؤثر بر خلاقيت ارائه كردهاند. به اعتقاد

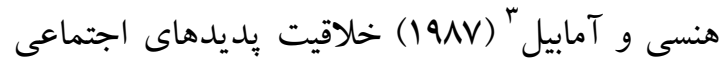

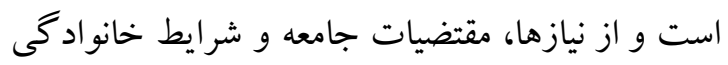
برمىخيزد. از سويى خلاقيت يك اثر شخصى است؛ يعنى به عواملى نظير انخيزش، هيجان، عواطف، احساسات، تجربهها و ياد گيرىهاى شخصى وابسته

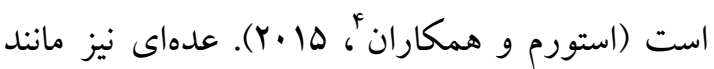

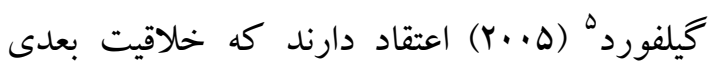
فراشناختى ودارد و با فر آيندهاى عالى ذهنى نظير تفكر، هوش، تخيل و بردازش اطلاعات ارتباط دارد.

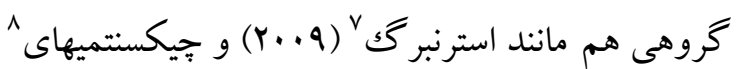

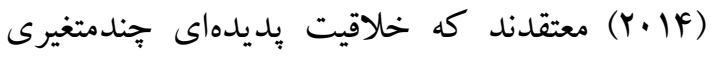
است يعنى عواملى نظير جامعه، خانواده، شخصيت و توانايىهاى شناختى همزمان بر آن تأثير مى گذارند. امروزه صاحبنظران، خلاقيت را دانشى بنيادى براى هر گونه تغيير و نوآورى و عاملى عاملى مهم در شتاب بخشيدن به نو آورىهاى علمى و فناورانه بشر مى ودانند.

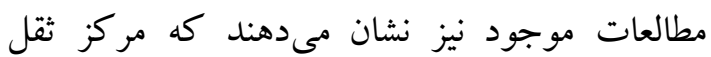

\footnotetext{
. Creativity

. Zbainos \& Lubart

3. Hennessey \& Amabile

4. Storm et al

5. Guliford

${ }^{6}$. Meta cognition

7. Sternberg

. Csikszentmihalyi
} 


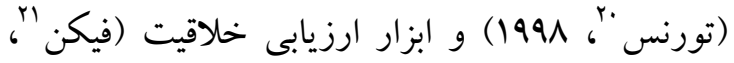
كه1911) كه مشكلات خاصى در مورد روايى، بايائى و

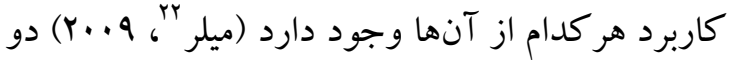
ابزار خود خزارشى نيز براى ارزيابى فرآيندهاى شناختى مرتبط با خلاقيت ايجادشدهاند. يرسشنامه تجديدنظر شده سبككاى خلاقيت (كومر، كملر و

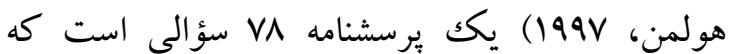
علاوه بر ارزيابى جندين عنصر ديخر خلاقيت ميزان استفاده و اعتقاد به فرآيندهاى شناختى مرتبط با لئ خلاقيت (براى مثال استفاده احساسات، استفاده از تكنيكها و عقايد در فرآيندهاى ناهشيار) را نيز موردبررسى قرار مىدهند. مقياس فر آيندهاى شناختى

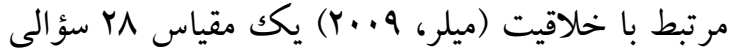
است كه عمدتاً به عقايد و ميزان استفاده از فر آيندهاى شناختى مرتبط با خلاقيت مى يردازد؛ اما اين مقياسها هم نقايصى داشتند، براى مثال برسشنامه تجديدنظر شده سبككهاى خلاقيت (كومار، كملر و هولمن "r آ، 199V) تمام فرايندهاى شناختى مرتبط با خلاقيت را بررسى نمى كند، درحالى كه مقياس فر آيندهاى شناختى مرتبط

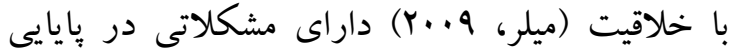
سازه و روايى زير مقياسها هست و نيازمند بررسىهاى

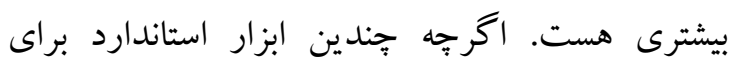
بررسى خلاقيت وجود دارد، باين حال ابزارهاى خود كزارشى محدودى براى بررسى توانايى و يا تمايل

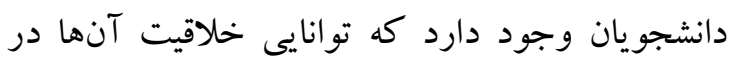
مطالعه را موردبررسى قرار دهد (روكاتن و مونتا"ج

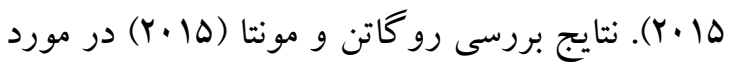
ويز گىهاى روانسنجى برسشنامه شناخت خلاق براى مطالعه روى دانشجويان دانشكاه لندن نشان داد كه ابزار

20. Torrance

${ }^{21}$. Fekken

22. Miller

23. Kumar, Kemmler \& Holman

${ }^{24}$. Rogaten \& Moneta
ويزگ گى انسانى جهانشمول و يكك سازه جندبعدى

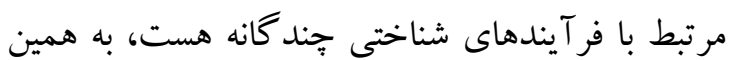
دليل با رويكرد "c كوجك)" در خلاقيت هم مرتبط

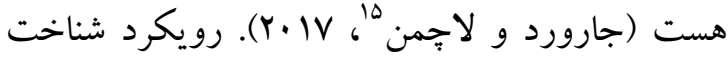
خلاق به مطالعه استفاده از فنها و راهبردهاى خلاق تفكر مى يردازد كه باعث ايجاد خلاقيت مىشوند. ازاينرو جندين فر آيند شناختى مرتبط با خلاقيت مانند

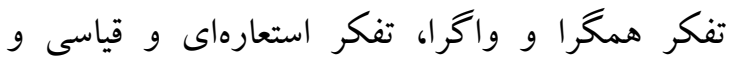

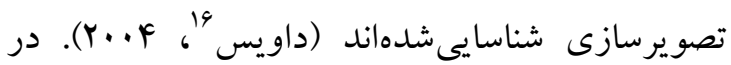
ديدكاه شناخت خلاق، اين بحث وجود دارد كه خلاقيت را با استفاده از آزمايش مى توان به بهترين

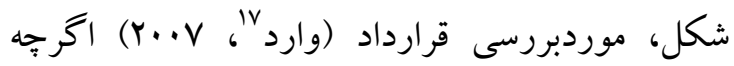
آزمايش اجازه مىدهد تا بفهميم كدام فر آيند شناختى منجر به تسهيل خلاقيت مى گردد، اما محدوديت آن عدم بررسى ارتباط بين خلاقيت و ديخر سازههاى روانشناختى در بافت واقعى زندگى است؛ بنابراين نياز به ابزار خود كزارشى وجود دارد كه در زمينهاى

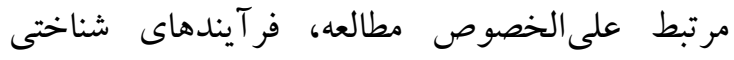
مرتبط با خلاقيت را موردبررسى قرار دهد. با توجه به اين مفهومسازى، خلاقيت در آموزش نقش دارد و به عنوان مهارتى در نظر گُرفته مىشود كه افراد را قادر

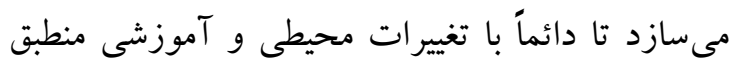
شوند و توانايى بالقوه خود را رشد دهند. باينحال، علىرغم نيمقرن تحقيق و بررسى هنوز هم در مورد

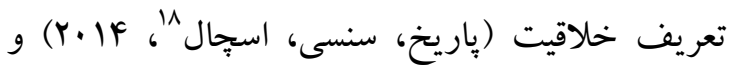
روشهاى اندازهيرى آن اختلافنظر اساسى وجود

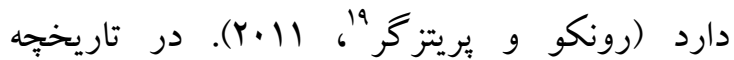
خلاقيت ابزارهاى جند كانهاى براى بررسى آن طراحى

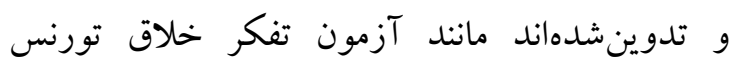

\footnotetext{
15 . Jaarsveld \& Lachmann

16. Davis

17. Ward

18. Parikh, Snee \& Schall
}

19. Runco \& Pritzker 
حجم نمونه توصيهشده براى تحليل عامل تأييدى حدود r.. كولدستين، 4. ×. لذا بر اساس نظرات مطرحشده در اين بزوهش با استفاده از روش نمونه گيرى در دسترس حجم نمونه ... نفر از دانشجويان دانشگاه سمنان در نظر كر فته شد. شيوه انتخاب نمونه بدين صورت بود كه از ميان سY دانشكدة دانشگاه سمنان بهصورت در

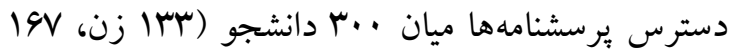
مرد) توزيع و جمع آورى گرديد. ملاككهاى ورود يزّوهش حاضر شامل I. دانشجوى مشغول به تحصيل r. حداقل مدرك تحصيلى ليسانس ب. تمايل داوطلبانه به شركت در يثزوهش و ملاككهاى خروج از بزوهش شامل ا. عدم تمايل به شركت در بُزوهش r. ناتوانى هاى جسمانى r. ير كردن ناقص برسشنامه

ابزار

فرم كوتاه مقياس شناخت خلاق برایى مطالعه بـ! اين مقياس توسط رو گاتن و مونتا (ها.Y) ساخته شد. داراى ه آيتم بوده كه شناخت خلاق در حين مطالعه را اندازه گيرى مى كند. اين برسشنامه بر روى يك طيف ليكرت ه كزينهاى از (كاملاً موافقم=ا تا كاملاً مخالفم=ه) قرار دارد. يرسشنامه هيج سؤال معكوسى ندارد. تدوين كنندكان اعتبار اين مقياس را با استفاده از روش آلفاى كرونباخ Ar/ • كزارش كردهاند. يرسشنامه

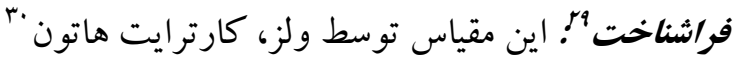
(Y. F (F) طراحىشده است. داراى .ب گويه هست كه باورهاى فراشناختى را اندازه گيرى مى كند. اين مقياس داراى ينج خرده مقياس است كه شامل: كنترل نايذيرى و خطر افكار كه روى غيرقابل كنترل بودن و خطرناكك

\footnotetext{
${ }^{28}$. Short use of creative cognition scale in studying

${ }^{30}$. Wells \& Cartwright-Hatton
}

از روايى و اعتبار مناسبى برخوردار بود. علاوه بر اين، مقياس شناخت خلاق براى مطالعه نسبت به ويز گیى هاى فراشناختى ناساز كارانه از اعتبار تفكيكى مناسبى برخوردار است. ازآنجايى كه نياز به ابزارى كوتاه و معتبر كه نه تنها ميزان استفاده از فرآيندهاى شناختى مرتبط با خلاقيت، بلكه شناخت خلاق در مطالعه را نيز مورد بررسى قرار دهد، به عنوان خلاء عمده بسيارى از ئزوهشهاى اين حوزه ديده مىشود، بر همين اساس داشتن ابزارى معتبر براى بررسى اين مسأله اين امكان را به معلمان و هم به بيزوهشخران ميدهد تا ميزان استفاده دانشجويان از شناختهاى خلاق را ارزيابى نمايند و مداخلاتى كه باهدف تسريع شناختهاى خلاق دانشجويان در مطالعه صورت مى گيرد را موردسنجش قرار دهند، لذا هدف از يزوهش حاضر بررسى ويز كى هاى روانسنجى نسخه فارسى يرسشنامه شناخت خلاق براى مطالعه هست. طرح جئوهش حاضر توصيفى و از نوع مطالعات روانسنجى است. جامعه آمارى اين يزوهش، كليه دانشجويان دانشخاه سمنان بودند كه در سال تحصيلى هوبا در اين شهر مشغول به تحصيل بودند. در مورد حجم نمونه لازم براى تحليل عاملى و مدلهاى ساختارى توافق كلى وجود ندارد (اسجريبر و و

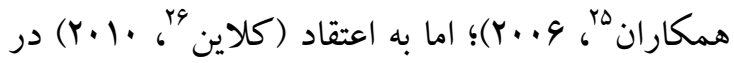
تحليل عاملى براى هر متغير · إيا ·ب نمونه لازم است؛ اما در تحليل عاملى تائيدى حداقل حجم نمونه بر اساس عاملها تعيين مىشود نه متغيرها. اكر از مدليابى معادلات ساختارى استفاده شود حدود ·r نمونه براى

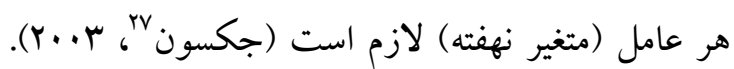

\footnotetext{
. Schreiber et al

26. Kline

27. Jackson
} 


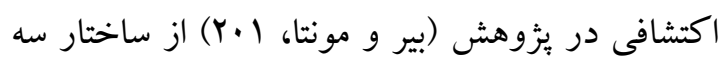

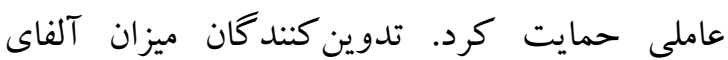
يرسشنامه را با استفاده از روش آلفاى كرونباخ براى هر

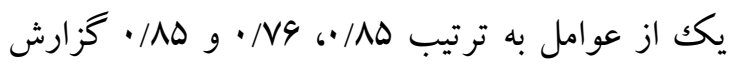
كردند. در بئوهش حاضر ميزان آلفا براى هر كدام از

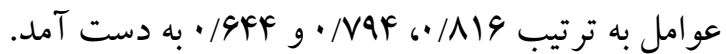

\section{روش اجرا}

بهمنظور اجراى مطالعات مقدماتى، ابتدا برسشنامه

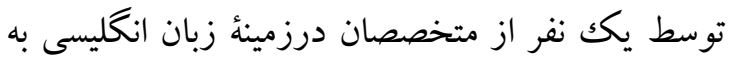
فارسى بر گردانده شد، سبس ترجمه بر گردان انجام شد. بسازآن برسشنامه در اختيار دو نفر از متخصصان روانشناسى تربيتى و روانسنجى قرار داده شد و مشكلات مربوط به ترجمه گويهها بررسى و رفع شد. در ادامه در يكك مطالعه مقدماتى يرسشنامه ترجمهشده در اختيار •ب نفر از دانشجويان قرار گرفت تا مشكلات اوليه ابزار در جمعيت نمونه مورد ارزيابى قرار گيرد. يس از جمع آورى برسشنامهها، تحليل مقدماتى دادهها نشان داد كه ابزار از قابليت مطلوبى در جمعيت نمونه برخوردار است. در ادامه بهمنظور توزيع نسخهُ نهايى مقياس شناخت خلاق براى مطالعه و ضمن ارائٔ توضيحاتى در خصوص اهميت و ضرورت يزوهش، گمنامى و محرمانه بودن اطلاعات از دانشجويان واجد شرايط دعوت به عمل آورده شد تا برسشنامهها را تكميل نمايند. همجنين بهمنظور جلو گيرى از سو گيرى

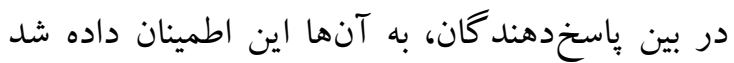
كه اين يرسشنامها كاربردى جزء در امر يُوهشى نداشته و هيج بِاسخ درست يا غلطى براى سؤالات يرسشنامه وجود ندارد. لازم به ذكر است در فرايند

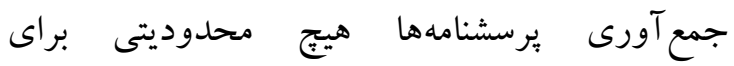
شركت كنندگان وجود نداشته و حتى المقدور سعى محقق بر اي بود كه برسشنامهها در زمانهاى مناسب در

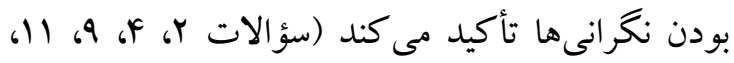

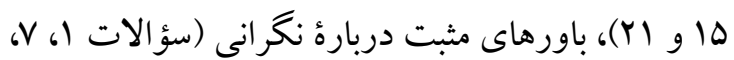

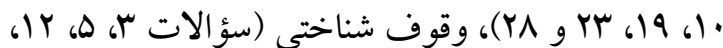

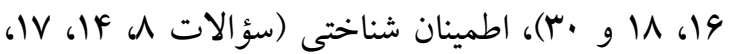

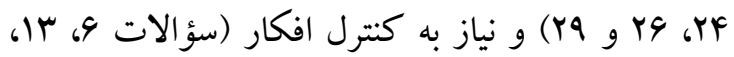

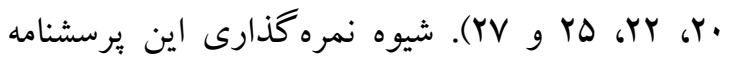
بهصورت مقياس جهاردرجهاى ليكرت از ا=موافق نيستم تا F=خيلى زياد موافقم مىباشد. همجنين اين ابزار داراى سؤالات معكوس هست. دامنه ضريب آلفاى كرونباخ براى خرده مقياسها را لVY/ • تا سو/• و

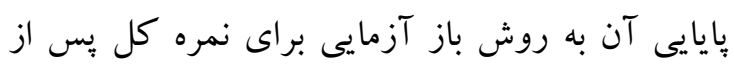

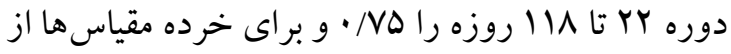
هوه • تا AV/ • گزارش كردهاند (ولز، كارترايت هاتون اعتبار اين مقياس در جامعه ايرانى با استفاده از (Y..F

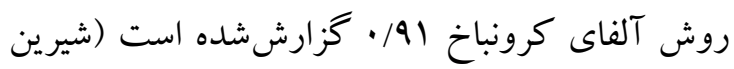

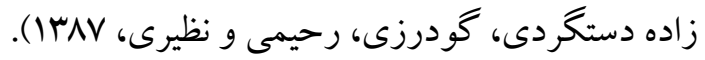
برسشنامه فراشناخت و فرا هيجان مثبت "إ از برسشنامه

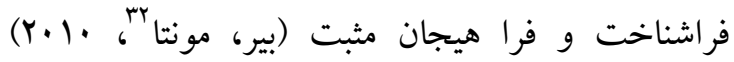
استفادهشده است. گويههاى اين برسشنامه بيانگر باورهاى فراشناختى در مورد فرايندهاى شناختى و

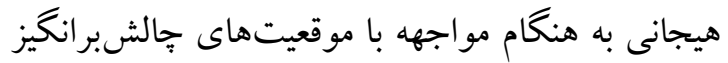
است كه بركرفته از مصاحبه هاى انجامشده در مطالعه

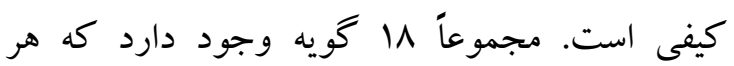
آزمودنى به اين گويهها با مقياس جهاردرجهاى (از

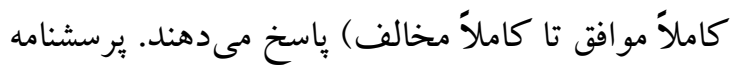
داراى سه زيرمقياس الف) اعتماد به خاموشسازى افكار و هيجانات بايدار؛ ب) اعتماد به تفسير هيجانات خود بهعنوان نشانه، جلو گيرى از واكنش فورى و تنظيم ذهن براى حل مسئله و ج (اعتماد به تنظيم سلسلهمراتب اهداف انعطافيذير و عملى است. تحليل عاملى

\footnotetext{
${ }^{31}$. Positive meta-cognition \& meta-emotion questionnaire . Beer \& Moneta
} 
تحليل عاملى اكتشافى: بهنظور تعيين خصوصيات روانسنجى :برسشنامه شناخت خلاق براى مطالعه از روش تحليل عاملى اكتشافى استفاده شد. بيش از

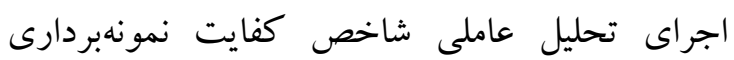
و مقدار آزمون كرويت بارتلت محاسبه شد.

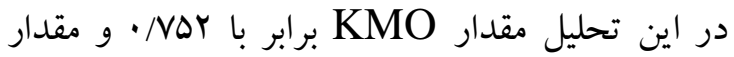
آزمون كرويت بارتلت برابر با هـIVN/VI به دست آمد

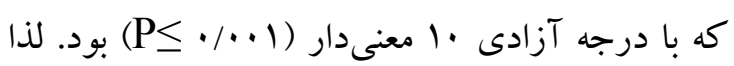
اجراى تحليل عاملى بر بايه ماتريس موردمطالعه نيز

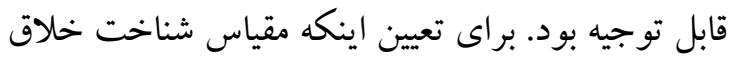
براى مطالعه از جند عامل اشباعشده، شاخصهاى ارزش ويزه، نسبت واريانس تبيين شده توسط هر عامل و نمودار اسكرى موردتوجه قرار گرفت. بر اين اساس

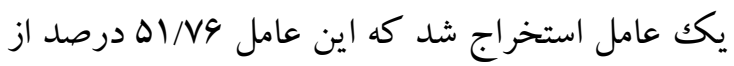
واريانس كل آزمون را تبيين مى كرد. بررسى نمودار اسكرى و جدول كل واريانس تبيين شده نشان مىدهد كه يكك عامل اوليه و بزرگك وجود دارد كه داراى

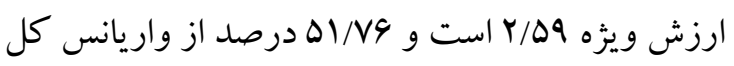
را تبيين مى كند. در جدول ا بارهاى عاملى سؤالات مقياس با استفاده از روش تعيين مؤلفهاى اصلى كز ارش شده است.
اختيار شركت كنند كان قرار داده شود. بهمنظور تحليل دادهها دو بخش توصيفى و استنباطى استفاده شد كه در سطح توصيفى از ميانگين و انحراف استاندارد و سطح استنباطى براى تحليل دادهها ابتدا از آزمون كايزر، ماير و الكين براى كفايت حجم نمونه و آزمون كرويت بارتلت براى بررسى توانايى عاملى بودن دادهها استفاده

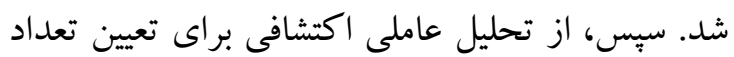
عوامل و تحليل عاملى تأييدى براى آزمون روايى سازه

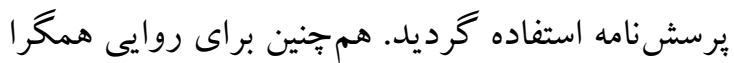
از همبستخى بيرسون و براى سنجش همسانى درونى از آلفاى كرونباخ استفاده شد. تمامى تحليل ها با استفاده از نرم|فزارهاى

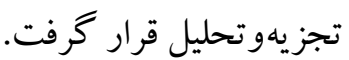

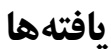

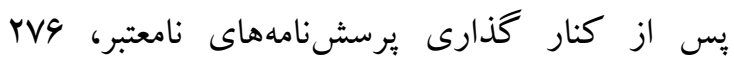

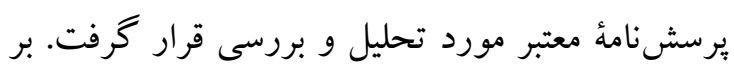

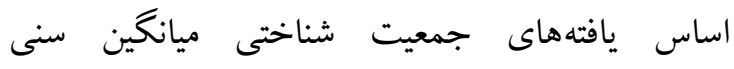
دانشجويان شركت كننده (YF/VF士 G/OV) و از اين تعداد كارشناسى 191 نفر (94/94.)، كارشناسى ارشد

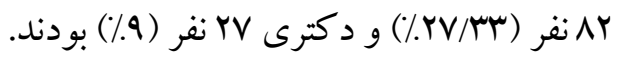

جدول 1. بارهاى عاملى سؤالات مقياس شناخت خلاق بر ایى مطالعه ( م=10)

\begin{tabular}{|c|c|c|}
\hline بار عاملى & كويلها & 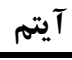 \\
\hline$\cdot /$ VAN & سعى مى كنم تا براى آكاهى از كار آمدى راهحل ها، آن را ايفا نمايم. & r \\
\hline$\cdot / \mathrm{V} 9 \Delta$ & درصورتى كه در گير مشكلى شوم، سعى مى كنم ديد كاههاى متفاوتى براى اين موقعيت اتخاذ نمايم. & r \\
\hline$\cdot / \mathrm{N} / \mathrm{D}$ & به هنگام كار بر روى هر جيز، سعى مى كنم در صورت امكان ايدهاى جديدى خلق نمايم & r \\
\hline$\cdot 19 \mathrm{VV}$ & به كارگيرى راهحل هاى قبلى به شيوه جديد منجر به ايدهاى خوبى خو اهد شد. & $\Delta$ \\
\hline .1990 & از طريق تلفيق جندين ايده، راهحل هاى مؤثرى مى يابم. & 1 \\
\hline
\end{tabular}

ا با 1990 • و بزرگكترين بار عاملى متعلق به سؤال مبا • / V91
همان كونه كه مشاهده مىشود همه بارهاى عاملى مناسب مىباشند. كو جككترين بار عاملى متعلق به سؤال 
برخى از شاخصها از برازندگى مناسبى برخوردارند و

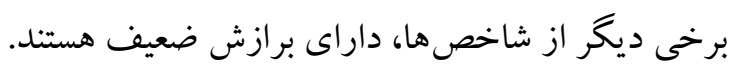

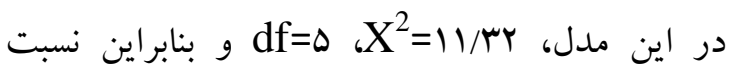

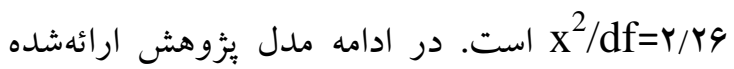

براى محاسبه روايى مقياس شناخت خلاق براى مطالعه از اجراى همزمان آن با ير سشنامه فراشناخت (

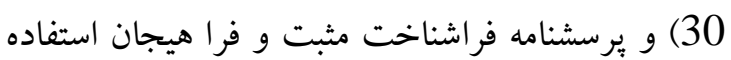
شد. متغيرهاى ذكرشده بهطور همزمان در بين وه 1 نفر از دانشجويان اجرا و اطلاعات حاصله با استفاده از ضريب همبستخى بيرسون تحليل گرديد (جدول r).

جدول ا. مدل نهايى مقياس شناخت خلاق براى مطالعه

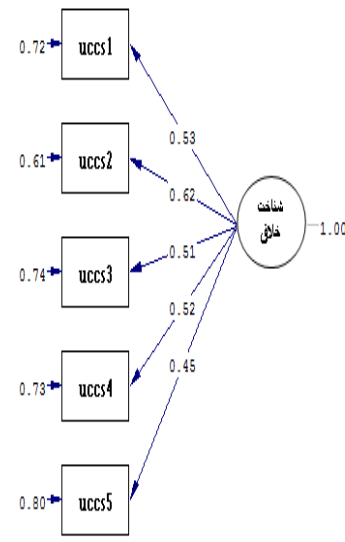

Chi-square=11.32, df $=5$, CFI $=0.91$, GrI $=0.91$, AGFI $=0.89$, RMSEA $=0.093$
تحليل عاملى تأييدى: بهمنظور برازش مدل تكك عاملى مقياس شناخت خلاق براى مطالعه از روش تحليل عاملى تأييدى استفاده شد. همان كونه كه قبلاً مطرح شد شرد ا 1ه نفر از خروه نمونه بهصورت تصادفى انتخابشده

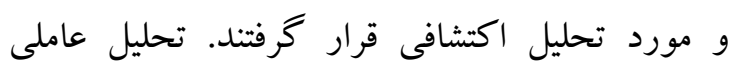
تأييدى بر روى \&\&1 آزمودنى باقيمانده اجرا شد كه فرارد

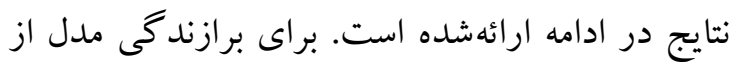

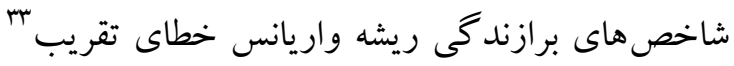

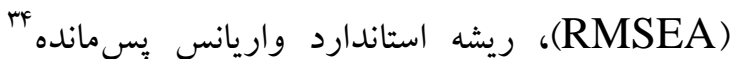

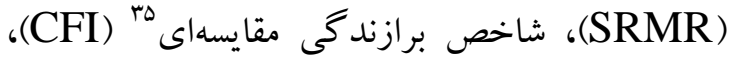
شاخص برازش نرم شده" (NFI) شاخص نيكويى

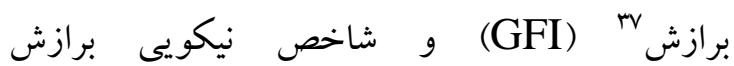

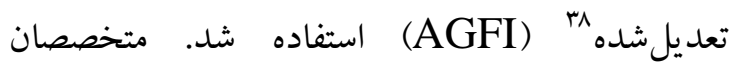
برشهاى متعددى را براى شاخصهاى برازش تعيين

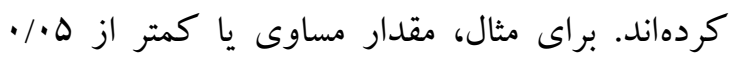
براى ريشه واريانس خطاى تقريب، مقدار مساوى يا بالاتر از 99/، براى شاخص برازندگى مقايسهاى و و

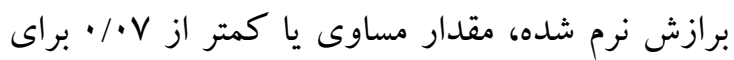

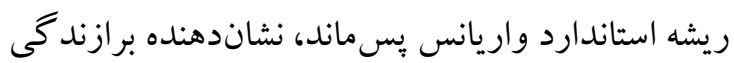

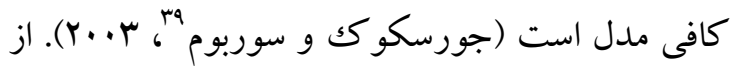

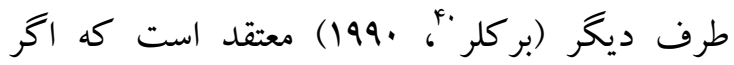

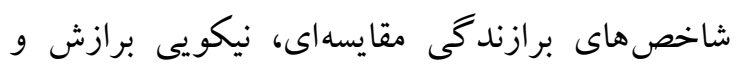

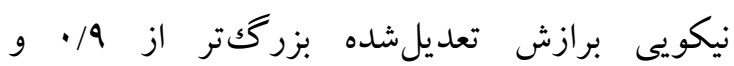
شاخصهاى ريشه واريانس خطاى تقريب و ريشه

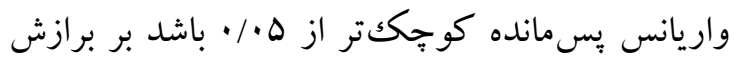
بسيار مطلوب و كوجككتر از / / بر برازش مطلوب

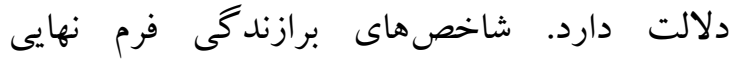
يرسشنامه بررسى شد. يافتها حاكى از آن است كه فران

\footnotetext{
33. Root Mean Square Error of Approximation.

34. Standardized Root Mean Square Residual.

35. Comparative Fit Index.

36. Normed Fit Index.

${ }^{37}$. Goodness of Fit Index.

${ }^{38}$. Adjusted Goodness of Fit Index.

${ }^{39}$. Joreskog \& Sorbom

40. Berkler
} 
جدول r. همبستكى مقياس شناخت خلاق براى مطالعه با فراشناخت، فراشناخت مثبت و فرا هيجان

\begin{tabular}{|c|c|c|c|c|c|}
\hline$r$ & $r$ & 1 & انحر اف استاندارد & ميانكين & 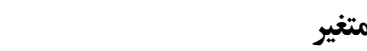 \\
\hline & & 1 & $r / .9$ & $19 / 94$ & ا. شناخت خلاق براى مطالعه \\
\hline & 1 & $\cdot / M r^{*}$ & $1 r / 90$ & $\vee \vee / \wedge l$ & 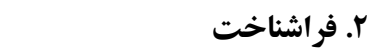 \\
\hline 1 & $\cdot / 9 \cdot 9 * *$ & $\cdot /$ rrr** & $9 / \wedge$. & $\Delta 1 / \Gamma$. & ع. فراشناخت مثبت و فرا \\
\hline
\end{tabular}

تحليل اعتباز: اعتبار مقياس شناخت خلاق براى مطالعه

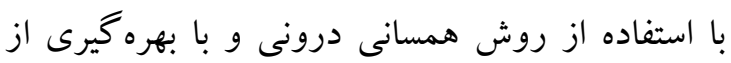
ضريب آلفاى كرونباخ محاسبه شد. در جدول زير

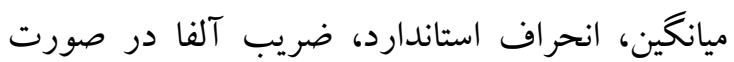
حذف آيتم و همبستكى هر سؤال با نمره كل آزمون

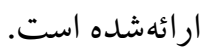

همان گونه كه در جدول فوق مشاهده مىشود، نتايج نشان داد، ميزان همبستگى بين شناخت خلاق براى

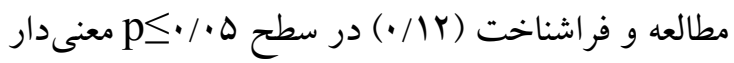
است. همجِنين بين شناخت خلاق براى مطالعه و فراشناخت مثبت و فرا هيجان (r/r/•) رابطه مثبت و

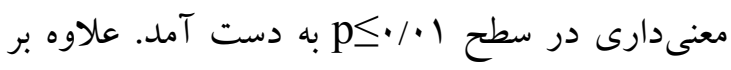
آن بين فراشناخت و فراشناخت مثبت و فرا هيجان (9-9/9 •) رابطه مثبت و معنى دارى مشاهده شد.

\begin{tabular}{|c|c|c|c|c|}
\hline آلفا در صورت حذف آيتم & همبستكى با نمره كل & انحر اف استاندارد & ميانكين & آيتم \\
\hline.$/ 9 A V$ & $\cdot / \mu \cdot r$ & - /AF & $F / Y F$ & 1 \\
\hline.$/ 90^{\circ}$ & $\cdot / 0 . \cdot$ & r/A & r/৭q & $r$ \\
\hline.$/ 94$. & . $/ \Delta r$. &.$/ 91$ & r/v & $r$ \\
\hline .1901 & . / Faf & $\cdot / \Lambda \Lambda$ & $r / \cdot r$ & $\varepsilon$ \\
\hline$. / 91 \mid$ & . AFY & $\cdot / 91$ & $f / \ldots$ & 0 \\
\hline
\end{tabular}

كاهش مى يابد، بنابر اين هيج كدام از سؤالات برسشنامه از مجموعه سؤالات كنار كذاشته نشد.

\section{بحث و نتيجه گيرى}

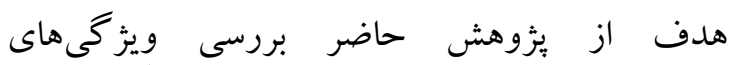
روانسنجى نسخه فارسى يرسشنامه فرم كوتاه شناخت خلاق براى مطالعه بود. براى تحليل دادهها از روش هاى تحليل عاملى، همبستخى ييرسون و ضريب آلفاى كرونباخ استفاده شد. نتايج تحليل عاملى اكتشافى نشان داد كه اين ابزار از يكك عامل تشكيلشده و تحليل
در جدول فوق ميانگين و انحراف استاندارد هر كدام از سؤالات يزٔوهش ارائهده است. سوى ديخً نتايج نشان داد كه اعتبار مقياس شناخت خلاق براى مطالعه، • همبستخى هر سؤال با نمره كل آزمون ارائهده كه نتايج نشان مىدهد همه همبستگىها مناسب بودند (بالاتر از م/•). افزون بر آن در جدول فوق ضريب آلفا در صورت حذف هر آيتم ارائهشده است. همان كونه كه مشاهده مىشود در صورت حذف يكى از آيتمها ميزان آلفا 
كرونباخ VI/ به دست آمد كه نشان از كه اعتبار رضايتبخش مقياس شناخت خلاق براى مطالعه و مطلوبيت ابزار در جمعيت دانشجويان ايرانى دارد. شناخت خلاق در مقايسه با ديخر سازههاى خلاقيت (مانند خلاقيت شخص، خلاقيت توليد و ...) يك سازه تحت بررسى است؛ بنابراين ارزيابى روايى سازه يرسشنامه شناخت خلاق مطالعه نيازمند بررسى دقيق ارتباطات آن است. در ادبيات نظرى و تجربى مجموعهاى از ارتباطات بين اين سازه با سازهاى

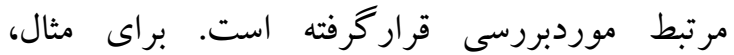
بررسىها نشان دادهاند كه شناخت خلاق براى مطالعه رابطه مثبت و متوسطى با عو اطف مثبت و رابطه منفى و ضعيفى با عواطف منفى دارد، بر اين اساس اين يافتهها نشان مىدهند كه عواطف مثبت عملكرد شناختى را تقويت مىنمايند (اسبادا، نيكسيوس، مونتا، ايرسون"

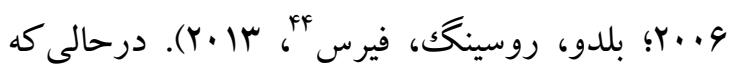
عواطف منفى مانع عملكرد شناختى مى گردند (كاسير

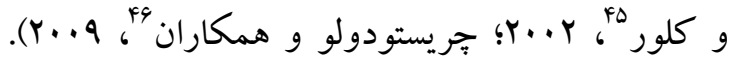
براى محاسبه روايى مقياس شناخت خلاق براى مطالعه

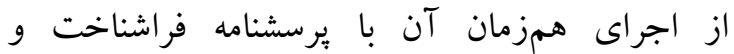
يرسشنامه فراشناخت مثبت و فرا هيجان استفاده شد. نتايج نشان داد كه ميان شناخت خلاق براى مطالعه با مران فراشناخت و فراشناخت مثبت و فرا هيجان رابطه مثبت و معنىدارى وجود دارد و اين يافتها با ويزوهش

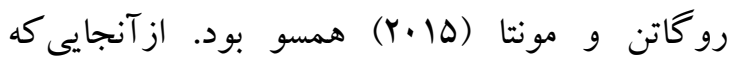
فراشناختها به افراد كمكك مى كنند تا انعطافيذير بوده و از طريق كنترل بر احساسات تصميم درست و

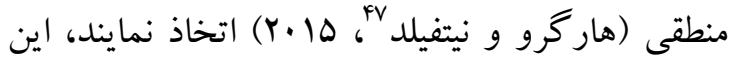
رابطه نشان مىدهد كه خلاقيت نيز ابعاد فراشناختى

\footnotetext{
43. Spada, Nikcevic, Moneta \& Ireson

${ }^{44}$. Bledow, Rosing \& Frese

45. Gasper \& Clore

${ }^{46}$. Christodoulou et al

47 . Hargrove \& Nietfeld,
}

عاملى تأييدى نشان داد مدل از برازش مناسبى برخوردار است. در همين راستا تكك عاملى بودن مدل با يافته هاى رو گاتن و مونتا (ها ·Y) همسو است. رو گاتن و مونتا (10) در هئوهشى با عنوان ساخت و هنجاريابى فرم كوتاه مقياس شناخت خلاق نيز به تكك عاملى بودن مقياس شناخت خلاق در دانشجويان اشاره كرد. شناخت خلاق از طريق يكك متغير جداكانه تعريف شده است كه ينج گُويه اين مقياس نشان دهند

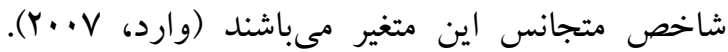
رويكرد شناخت خلاق به اين موضوع اشاره مى كند

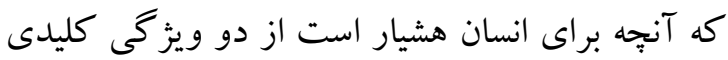
برخوردار است: آنها اصيل، نو، مفيد و عملى هستند، همجِنين آنها براى وظايف انسان مناسب هستند. در ديدكاه شناخت خلاق، عقايد و توليدات محسوس ذهن كه نو و مفيد هستند ناشى از كاربرد فرايندهاى شناختى معمولى و بنيادى براى ساختار دانش موجود

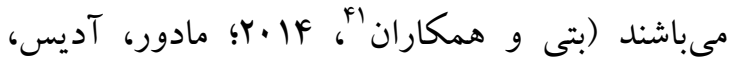

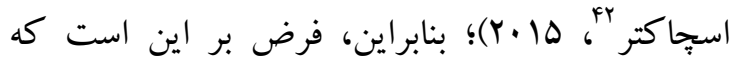
مطالعات در اين زمينه بايد به شيوهاى طراحى شوند كه قادر به ايجاد بينش مفيدى در زمينه شناختها و يا

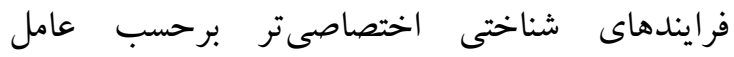

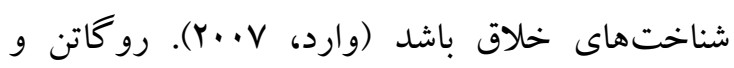
مونتا (Q1) (Y) در بررسى اعتبار مقياس شناخت خلاق بر روى جمعيت هاى مختلف دانشجويان از قبيل جينى، زاينى، هندى، آفريقايى، ارويايى اعتبار مقياس شناخت

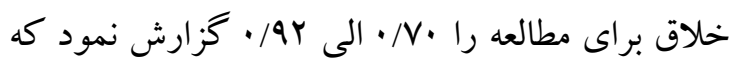
نشان از اعتبار مناسب اين مقياس در جمعيتهاى مختلف داشت، اين در حالى است كه در يثوهش سئ حاضر نيز به منظور بررسى اعتبار مقياس شناخت خلاق براى مطالعه، با روش همسانى درونى ضريب آلفاى

\footnotetext{
41 . Beaty et al.

${ }^{42}$. Madore, Addis \& Schacter
} 
منطقى اتخاذ نمايند. در اين زمينه بررسى ادبيات يثزوهشى نشان مىدهد كه دانشجويانى كه از سطوح فراشناختى بيشترى برخوردارند بيشتر مىتواند از شناخت هاى خلاق استفاده نمايند كه اين مسئله نشان مى دهد كه فراشناخت در حل خلاقانه مسائل نقش

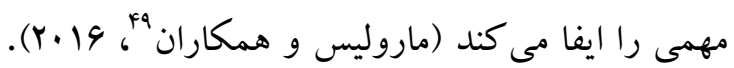
درواقع اين خود آكاهى شناختى منجر به آكاهى فرد از

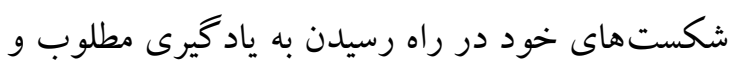
آكاهى از نياز به استفاده از شناختهاى خلاقانه به منظور رسيدن به اهداف يادگيرى است. علاوه بر اين نياز به كنترل افكار با توانايى اجتناب از افكار خود كار مرتبط است كه مىتوانند در صورت لزوم تغيير از شناخت هاى معمولى به شناختهاى خلاق را تسهيل

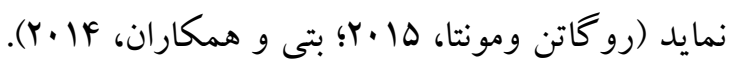
اين يافته ها بيشنهاد مى كنند كه هنگامى كه رفتارها و فعاليت هاى شناختى بايد به سمت انجام تكاليف هدايت شوند، توانايى خود انعكاسى تجارب و آكاهى از هيجانها و خود نظم دهى به فرايند استفاده افراد از راهبردهاى شناختى منجر به خلاقيت كمكك مى كند

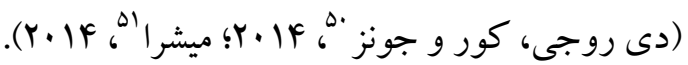
با توجه به نقش مهم شناخت خلاق در استفاده از راهبردها و فنون خلاقانه در فرايند ياد گيرى و نقش آن در ايجاد خلاقيت در بين دانشجويان (داويس، F+... و و نظر به سهولت اجرا، نمره گذارى، تعبير و تفسير، قابليت اجرا، عملى بودن و روايى و اعتبار مناسب، نتيجه گرفته مىشود كه اين مقياس ابزار مناسبى براى اندازهگيرى شناخت خلاق در ميان دانشجويان است. نظر به اينكه هيج يزّوهشى خالى از محدوديت نيست، نخستين محدوديت مطالعه حاضر آن است مشخص نيست نمرات حاصل از اين ابزار تا جه اندازه با رفتارهاى

\footnotetext{
49. Marulis et al

${ }^{50}$. de Rooij Corr \& Jones

51. Mishra
}

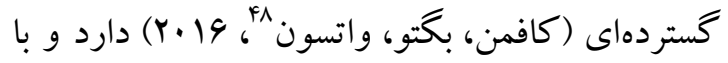
فر آيندهاى عالى ذهنى نظير تفكر، هوش، تخيل و يردازش اطلاعات ارتباط است در همين راستا است

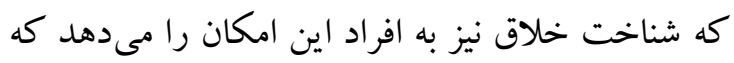

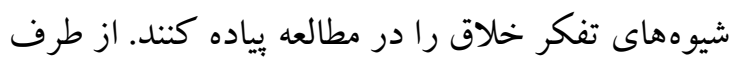
ديخر هيجانات و فرا هيجان نيز مىتو اند بر خلاقيت فرد

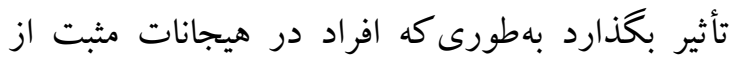

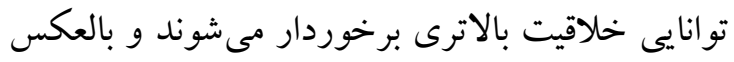

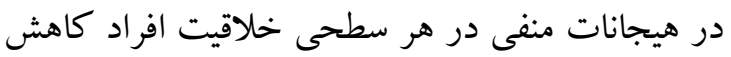
مى يابد و در همين راستا است كه عملكرد افراد نيز در فرايندهاى عالى ذهن و مطالعه كاهش مى يابد. فراشناخت خود نظم دهى فرآيندهايى است كه در بردارنده تلاش براى خاموشسازى تداوم جالش، تفسير احساسات خود به عنوان نشانه، بازداشتن از واكنش سريع و تنظيم ذهن براى حل مسئله و تمركز بر تكليف و تنظيم سلسلهمراتب اهداف انعطاف يذير و و و عملى مىباشند. جنين فراشناختى بلهورمعمول به به به شناسايى الكوى فرايندهاى فراشناختى و فراهيجانى شامل فعاليتهاى خودتنظيمى عملكرد اجر ايى كوتاه و يايدار مى يردازد و به دنبال تغيير يردازش فراشناختى متمركز بر مشكل، به حل مشكل و و يا برآمدن از تكليف و از اين است مىباشد (بير و مونتا، ·. (Y). رابطه مثبت و معنى دار بين شناخت خلاق با فراشناخت و فراشناخت و فرا هيجان مثبت مؤيد اين مسئله است كه آن دسته از افرادى كه قادر به بهره گيرى از راهبردهاى شناختى خلاقانه هستند در برخورد با مشكلات بهخوبى مىتواند با استفاده از رويكرد حل

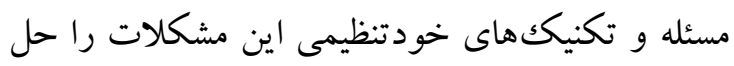

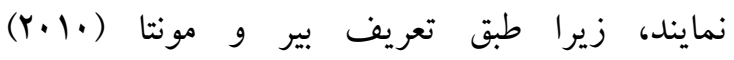
فراشناختها به افراد كمكك مى كنند تا انعطافيذير بوده و از طريق كنترل بر احساسات تصميم درست و

${ }^{48}$. Kaufman, Beghetto \& Watson 


\section{References}

Beaty, R. E., Silvia, P. J., Nusbaum, E. C., Jauk, E. and Benedek, M., 2014. The roles of associative and executive processes in creative cognition. Memory \& cognition, 42(7), pp.1186-1197.

Beer, N. and Moneta, G.B., 2010. Construct and concurrent validity of the positive metacognitions and positive meta emotions questionnaire. Personality and Individual Differences, 49(8), pp.977-982.

Bledow, R., Rosing, K. and Frese, M., 2013. A dynamic perspective on affect and creativity. Academy of Management Joumal, 56(2), pp.432-450.

Breckler, S. J., 1990. Applications of covariance structure modeling in psychology: Cause for concem?. Psychological bulletin, 107(2), p.260.

Brun, S, Heidari., A, Bakhtiyarpour, S. and Brun, S., 2012. The Effect of Creative Problem Solving Education on Students' Creativity Components. Journal of Criticism and Innovation in the Humanities, 4(2), pp. 5671.

Chakrabarty, A. and Chuan Tan, K., 2007. The current state of six sigma application in services. Managing Service Quality: An Intemational Journal, 17(2), pp.194-208.

Christodoulou, C., Melville, P., Scherl, W.F., Macallister, W.S., Abensur, R.L., Troxell, R.M. and Krupp, L.B., 2009. Negative affect predicts subsequent cognitive change in multiple sclerosis. Joumal of the International Neuropsychological Society, 15(1), pp.53-61.

Csikszentmihalyi, M., 2014. Toward a psychology of optimal experience. In Flow and the foundations of positive psychology (pp. 209226). Springer Netherlands.

Davis, G.A., 2004. Creativity is forever. Kendall Hunt Publishing Company.

de Rooij, A., Corr, PJ. and Jones, S., 2015, June. Emotion and creativity: Hacking into

cognitive appraisal processes to augment creative ideation. In Proceedings of the 2015 ACM
واقعى در زندگى روزمره مرتبط است. محدوديت دوم

اين ابزار مربوط به قلمرو مكانى و زمانى مطالعه است.

اين مطالعه بر روى دانشجويان دانشگاه سمنان صورت

كرفته است و لذا نمى توان يافتهاى آن روان رابه ساير

شهرها و اقشار تعميم داد و در صورت تعميم دهى بايد

جوانب احتياط رعايت شود. بر اساس اين

محدوديتها، بيشنهاد مىشود نمرات شناخت خلاق

براى مطالعه با اندازههاى رفتار واقعى در زندگى

روزمره همبسته شود تا شواهدى از بسط نمرات حاصل

از تشخيص اين ابزار در موقعيتهاى واقعى زندگى

فراهم شود. بدين معنا كه هنوز مشخص نيست كه كه آيا

نمرات بالا در اين يرسشنامه توان يِيشينى رفتارهاى

عملى را دارد يا خير؟ همجنين، به بُزوهشخران بِيشنهاد

مىشود كه در آينده مطالعاتى را طرحريزى كنند كه ضمن تشخيص نمرات برش دقيق اين ابزار، كاربردهاى عملى نمرات اين ابزار را در بيشبينى رفتارهاى واقعى در محيط زندگى فرد تشخيص دهند. افزون بر آن بررسى روايى نمرات حاصل از اين ابزار به عنوان ابزارى براى تشخيص حساسيت اثر مىتواند محور ديخرى از بثزوهشهاى مناسب در مورد اين ابزار باشد. همجين بيشنهاد مىشود رابطه شناخت خلاق براى مطالعه با متغيرهاى مختلف سلامت روانى، عملكرد خلاق در مدارس و روابط اين سازه با ساير سازهها كه قابليت بيشترى در برنامهريزىهاى مربوطه دارد، حاصل

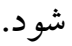

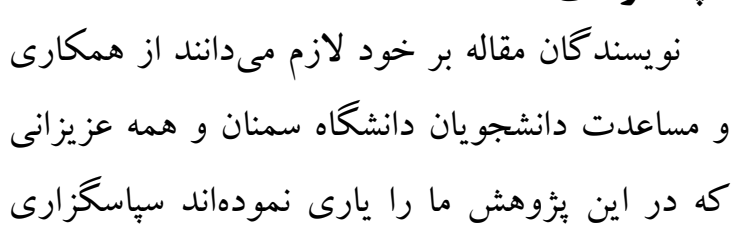
نمايند. SIGCHI Conference on Creativity and Cognition (pp. 265-274). ACM. 
Gage, N.L. and Berliner, D.C., 1994. Educational psychology. Hopewell.

Gasper, K. and Clore, G.L., 2002. Attending to the big picture: Mood and global versus local processing of visual information. Psychological science, 13(1), pp.34-40.

Guilford, J.P., 1967. The nature of human intelligence.

Hargrove, R.A. and Nietfeld, J.L., 2015. The impact of metacognitive instruction on creative problem solving. The Journal of Experimental Education, 83(3), pp.291-318.

Hennessey, B.A. and Amabile, T.M., 1987. Creativity and Leaming: What Research Says to the Teacher. National Education Association, Professional Library, PO Box 509, West Haven, CT 06516.

Jaarsveld, S. and Lachmann, T., 2017. Intelligence and creativity in problem solving: the importance of test features in cognition research. Frontiers in psychology, 8, p.134.

Jackson, D.L., 2003. Revisiting sample size and number of parameter estimates: Some suppoit for the N: q hypothesis. Structural equation modeling, 10(1), pp.128-141.

Jang, S.H., 2015. Development of Implicit Memory: The Effect of Knowledge Base and Meta Memory. The Journal of the Korea Contents Association, 15(9), pp.639-651.

Jöreskog, K.G. and Sörbom, D., 1996. PRELIS 2 user's reference guide: A program for multivariate data screening and data summarization: A preprocessor for LISREL. Scientific Software International.

Karami Darabkhani, R., Agahi, H., Shiri, N. and Gholami, M., 2012. The Role of Thinking Styles in the Creativity of Agricultural Students (Case Study, Faculty of Agriculture, Razi University of Kermanshah). Journal of journalism and creativity in the humanities, 2(1), pp.60-82.

Kaufman, J.C., Beghetto, R.A. and Watson, C., 2016. Creative metacognition and self-ratings of creative performance: A 4-C perspective. Learning and Individual Differences, 51, pp.394-399.

Kline, R.B., 2010. Principles and Practice of Structural Equation Modeling, 3rd edn GuilfordPress. New York.
Kumar, V.K., Kemmler, D. and Holman, E.R., 1997. The Creativity Styles QuestionnaireRevised. Creativity Research Journal, 10(1), pp.51-58.

Madore, K. P., Addis, D. R., \& Schacter, D. L. (2015). Creativity and memory: effects of an episodic-specificity induction on divergent thinking. Psychological science, 26(9), 1461-1468.

Marulis, L.M., Palincsar, A.S., Berhenke, A.L and Whitebread, D., 2016. Assessing metacognitive knowledge in 3-5 year olds: the development of a metacognitive knowledge interview (McKI). Metacognition and Learning, 11(3), pp.339368.

Miller, A.L., 2009. Cognitive processes associated with creativity: Scale development and validation.

Mishra, S., 2014. Creative thinking of high school students in relation to their emotional intelligence. Journal of Psychology and Behavioral Science, 2, pp.197-204.

pirkhaefi, A., Borjali, A., Delaware, A. and Eskandari, H., 2009. The Effect of Creation Education on Metacognitive Components of Students' Creative Thinking. Journal of Management and Educational Management of Islamic Azad University, Garmsar Branch, 3(2), pp. 51-61.

Pritzker, S.R. and Runco, M.A., 1999. Encyclopedia of Creativity, Two-Volume Set, Volume 12.

Rogaten, J. and Moneta, G.B., 2015. Development and validation of the short use of creative cognition scale in studying. Educational Psychology, 35(3), pp.294-314.

Rogaten, J. and Moneta, G.B., 2015. Development and validation of the short use of creative cognition scale in studying. Educational Psychology, 35(3), pp.294-314.

Shah, R. and Goldstein, S.M., 2006. Use of structural equation modeling in operations management research: Looking back and

forward. Joumal of Operations Management, 24(2), pp.148-169.

Shirinzadeh Datgiri, S., Goodarzi, M.A., Rahimi, Ch. and Nazari, Gh., 2008. 
Factor Structure, Validity and relability of the MetaCognitive Questionnaire 30 Questions. Joumal of Psychology, 12(4), pp. 445-461.

Spada, M.M., Nikcevic, A.V., Moneta, G.B. and Ireson, J., 2006. Metacognition as a mediator of the effect of test anxiety on a surface approach to studying. Educational Psychology, 26(5), pp.615-624.

Stemberg, R.J. and Kagan, J., 1986. Intelligence applied: Understanding and increasing your intellectual skills. Harcourt Brace Jovanovich.

Storm, B.C., Angello, G., Buchli, D.R., Koppel, R.H., Little, J.L. and Nestojko, J.F., 2015. A review of retrieval-induced forgetting in the contexts of learning, eyewitness memory, social cognition, autobiographical memory, and creative cognition. In Psychology of Learning and Motivation (Vol. 62, pp. 141194). Academic Press.

Torrance, E.P., 1998. Torrance tests of creative thinking: Norms-technical manual: Figural (streamlined) forms $A \& B$. Scholastic Testing Service.

Ward, T.B., 2007. Creative cognition as a window on creativity. Methods, 42(1), pp.28-37.

Wells, A. and Cartwright-Hatton, S., 2004. A short form of the metacognitions questionnaire: properties of the MCQ-30. Behaviour research and therapy, 42(4), pp.385-396.

Yokochi, S. and Okada, T., 2005. Creative cognitive process of art making: A field study of a traditional Chinese ink painter. Creativity Research Journal, 17(2-3), pp.241-255 